O. Markova,

Candidate of Law Science, Associate Professor, Associate Professor at the Department of Legal Disciplines Sumy Branch of the Kharkiv National University of International Affairs

\title{
COMPARATIVE LEGAL ANALYSIS TYPES OF ADMINISTRATIVE PROCEDURE
}

Within the framework of a comparative legal study, we consider the doctrinal and legislative approach of foreign countries in this matter. It should be noted that in most works by European and American scientists, the concept of "types of administrative procedure" is found. Scientists devote more substantial content to different types of administrative procedure within a particular type than to the semantic meaning of the terms "view, a type".

Legislation on administrative procedure in countries such as Germany and the United States with respect to fixing different types of administrative procedure is a "model" from the point of view of the legislator's application of a systematic approach. Turning to the provisions of the Federal Act on Administrative Procedure for fixing the types of administrative procedure, we note that the types of administrative procedure depend on the type of rulemaking: formal, informal, exclusive, hybrid and conciliation.

Under the "rulemaking" is understood - the agency process of developing, amending or repealing the rules. A rule is a statement of a general or specific (private) nature intended to implement, interpret a law or policy, as well as to describe organizational, procedural requirements of an agency. Rules adopted in According to certain legal requirements, the agencies within the competence of the authorities have the force of law. The Supreme
Court in one of its decisions ruled that the regulatory act of the agency has the force of law and liability is provided for its violation.

Formal, informal, and exceptional rulemaking differ in the degree to which individuals are involved in the agency's adoption of rules. This rule acquires a greater degree of legitimacy and inspires confidence on the part of the public or specific individuals who are the recipients for which they are accepted. Most federal agencies develop rules through "informal" rule-making". The informal procedure is also called the notification and commentary procedure, which is regulated by Art. 553 APA. According to Art. 553 the agency is obliged to ensure public participation in the process of informal rule-making by notifying the rules of the Federal Register. Then the company is given the opportunity to comment on the content of the proposed rule for a certain period. For the agency, feedback from the public is a prerequisite on the one hand - for making an effective decision, and on the other - for following the rules. Despite the fact that the APA sets a minimum degree of public participation in the rule-making procedure, in the informal procedure the Act provides an opportunity to exercise the right to participate" [1]. We considered the stages of this procedure in question 2.3 , so we will not dwell on them. 
The formal procedure is regulated by Art. 556 and $557 \mathrm{APA}$. In general, agencies usually adopt the rules through an informal procedure, however, in cases prescribed by law or at the request of Congress, rulemaking can be carried out through a formal procedure. Formal rule-making is rule-making, which is carried out according to the principle of a judicial process: the parties provide evidence, cross-examine witnesses in order to obtain reliable facts. The decision is made in accordance with strict procedural requirements similar to a court decision. This procedure is carried out by an administrative judge or an agency official who is empowered judges in the proceedings. Communication between interested parties and agency officials involved in the process of formal rule-making is prohibited by law.

Exceptional rulemaking. In this procedure, public involvement is optional, the agency is governed by administrative discretion. The Federal Administrative Procedure Act defines the areas covered by the application of exclusive rulemaking: military or foreign policy issues; - management of the agency or its personnel or public property, loans, subsidies, cash assistance and contracts; - interpretation rules, general policy statements or organization rules, agency procedures and practices; - in cases where the agency reasonably decides that the public procedures for the adoption of the act have no practical value, are redundant or contrary to public interests.

Hybrid rulemaking is applied in two cases: 1) at the request of the federal court; 2) at the request of Congress. Rulemaking is called so because they combine legislative rulemaking procedures and formal judicial procedures. This rulemaking is more flexible than the formal rulemaking procedures according to $\S 556$ and $\S 557$, and then the informal rulemaking procedures according to
$\S 553$ with regard to ensuring wider public participation. The internal structure of this procedure resembles a formal one: the agency must hold hearings; provide an opportunity for interested parties to give oral evidence; cross-examine.

The most common additional procedures are procedures: crossexamination of experts, additional periods for comments. They are used in cases where rule-making has a significant impact on a small number of stakeholders. Courts may require the agency to adopt a hybrid procedure, guided by the concept of "due process" to maximize the protection of concerned.

Conciliation rulemaking (contractual) is an addition to the traditional informal rulemaking procedures, which allows agencies to consult with stakeholders at the stages of developing the rules and is regulated by Art. 561 APA. The purpose of such a rulemaking is to increase administrative efficiency and reduce subsequent opposition by involving external groups with significant interest in the subject of the rule. Harmonized rulemaking is a process in US administrative law used by federal agencies in which representatives of the federal agency and interest groups discuss the terms of the proposed administrative rules. The agency publishes the proposed rule in the Federal Register, and then the rule goes through all stages of the informal rule-making procedure.

Conciliation rulemaking allows the agency and other interested parties to reach a consensus in the early stages of rulemaking with the aim of making a final acceptable decision (final rule) for all parties. In accordance with The Negotiated Rulemaking Act of 1996 the head of the agency is authorized to "create a rulemaking committee to develop and agree on the proposed rule". The rulemaking committee consists of a maximum of 25 members. If, as a result of negotiations, the committee 
reaches a consensus on the proposed rule, it will prepare a report on the proposed rule; if not, it will prepare a report only on those paragraphs of the rule on which it was possible to achieve consistency. The reports and conclusions of the committee are not binding on the agency.

This rulemaking procedure ends with an informal notification and commenting process. Usually, an agency uses agreed rulemaking at its discretion, but in some cases, Congress may require agencies to comply with the requirements for an agreed rulemaking process when adopting specific rules.

The approach of the American legislator in relation to the types of administrative procedure is characterized by a number of features that distinguish them from types in other countries. Firstly, the legislatively legitimate opportunity for citizens to take an active part in the procedure of informal rule-making; secondly, the duality of procedures - combining at least several procedures in one procedure; thirdly, the agency's discretion regarding the choice of one of the above procedures, which may be limited by both the Congress and the federal judge; and fourthly, the types presented administrative procedure laid the rulemaking type.

The draft Ukrainian legislation draws on the experience of the Code of Administrative Procedure of Poland [2]. Consider the provisions that govern the types of administrative proceedings, in particular: general administrative proceedings, issuance of certificates, proceedings on complaints and applications. The legislative approach is based on the typical nature of appeals. The doctrine, in order to expand the species diversity of production, uses the classification method. Scientists propose to group administrative proceedings in two large groups: jurisdictional and nonjurisdictional. As a criterion that allows to distinguish between production, they use the form of objectification of results (administrative decision).

Jurisdictional proceedings (Postępowanie jurysdykcyjne) include: general administrative proceedings; special administrative proceedings. Non-jurisdictional proceedings (Postępowanie niejurysdykcyjne) include: production of certificates (Postępowanie w sprawie wydawania zaświadczeń), proceedings on complaints and applications (Postępowanie w sprawie skarg i wnioskyw), and competent (Postępowanie kompetencyjne) [3, p. 52].

Jurisdictional proceedings are regulated by sections I, II, IV, IX and $\mathrm{X}$ of the Code and are applied in the jurisdictional activities of all public administration authorities, in cases where the law does not establish special restrictions on the scope of application [4]. The result of a jurisdictional procedure is the adoption of an administrative decision. The peculiarity of this procedure is its two-instance nature: if the person in respect of whom the administrative act was adopted does not agree with him, he can appeal it to the appeals body, i.e. in the body of second instance. Consequently, the administrative case will be reviewed and decided twice by the government. In the construction of two-instance procedure there is an important point that you can appeal only the final decision. Decisions are final when:

- within the time period established by the Code appeal was filed;

- the decision was made by a body of second instance, which is a body of last resort.

For example, the head of the community, as a body of first instance, makes an administrative decision to refuse to provide housing allowance. Within 14 days after receiving this decision, you can appeal it to the Appeal Council of local self-government the Appeal Commission of local selfgovernment is a body of second instance. 
The most common type of jurisdictional administrative procedure is general administrative procedure, which is applied by government bodies and other entities on the basis of the provisions of the Code of Administrative Procedure and based on the results of which an administrative act is adopted.

Special administrative and jurisdictional proceedings are characterized by special legal regulation and the subject area. First of all, the provisions of special laws apply to such procedures in the matter of regulation, and then the general provisions of the Code. In a situation where the act regulating this special proceeding does not contain provisions relating to this proceeding, the provisions of the Code of Administrative Proceedings apply. Special production, like general production, ends with a decision by the state administration body.

Such proceedings include: Enforcement proceedings, which are regulated by the special Law of 06.17.1966 "On Enforcement Proceedings in the Administration". The goal is to ensure through the application of measures of state coercion, the fulfillment of obligations arising from an administrative act.

Control and supervisory proceedings. The purpose of the control proceedings is to study the administrative case, evaluate it from the point of view of compliance with the rule of law, and in cases of violations, find out the causes of their occurrence and formulate recommendations on eliminating negative consequences and preventing their occurrence in the future. Control procedures are carried out by the Supreme Audit Office and are regulated by the Law of Poland of 07.15.2011 "On Control in Government Agencies". The purpose of the supervisory proceedings coincides with the objectives of the control procedure, but is supplemented by the application of measures that affect the activities of the controlled body in case of violations [5, p. 82].

Legislative proceedings. The goal is the adoption of a normative act by a government body; (procedure for adopting a local spatial development plan).

Non-jurisdictional proceedings. Its purpose is to confirm certain facts or legal status or to evaluate the functioning of government bodies. This procedure includes: Production of certificates is regulated by section VII of the Code of Administrative Procedure, as well as section VIIIa of the Tax Code. The certificate is an official document that is issued at the request of a person by a competent public administration body confirming a specific fact or legal status.

The processing of complaints and petitions regarding complaints and petitions is regulated by section VIII of the Code of Administrative Procedure. The purpose is to assess the quality of functioning of bodies and institutions referred to in Art. $221 \S 1$ of the Code of Administrative Procedure by filing (by an individual or collective person) a complaint; - consider proposals for improving the activities of entities referred to in Art. $221 \S 1$ of the Code of Administrative Procedure. The Constitution of the Republic of Poland guarantees every citizen the right to submit petitions, complaints and petitions to state and local authorities, as well as to public organizations and institutions. The subject of the complaint may be improper fulfillment of tasks by the state governing body, as well as prolonged or bureaucratic resolution of issues. The subject of the application is proposals to improve the quality of the work of bodies or to prevent abuse of authority by authorities [6, p. 323].

It is forbidden to prosecute citizens and members of their families for submitting an appeal to bodies of state power, local self-government, enterprises, institutions, organizations, regardless of ownership, associations 
of citizens, officials, for criticizing their activities and decisions. The competent procedure is applied in cases of a dispute between government bodies. The dispute may be negative or positive. A positive dispute arises between bodies that consider themselves competent in deciding on a given case, while a negative dispute arises in cases where no body considers itself competent in deciding on an administrative case. Competent proceedings are conducted in higher government bodies, or in administrative courts.

For example, the body authorized to resolve the dispute between the Masovian Voivodeship and the Lublin Voivodeship will be the minister responsible for public administration - minister właściwy do spraw administracji publicznej.

The approach of the Polish legislator regarding the types of administrative proceedings differs from the approach of the first two countries in a differentiated manner. The Code of Administrative Procedure reflects a general approach, since the collected types of production cover the main areas of activity of government bodies, and with regard to special types of production - the legislator has provided special regulation.

The last country to consider is France. In this country, the main reason that influenced the separation of the administrative procedure into the controversial and non-controversial was the separation of the judicial administration (in order to maintain its independence) from the administration (executive administration), which directly performs administrative functions in the country.

For a long time historically, the Council of State was the only administrative judicial institution in France that played a key role in the formation of administrative justice. His powers were primarily related to the out-of-court settlement of conflicts

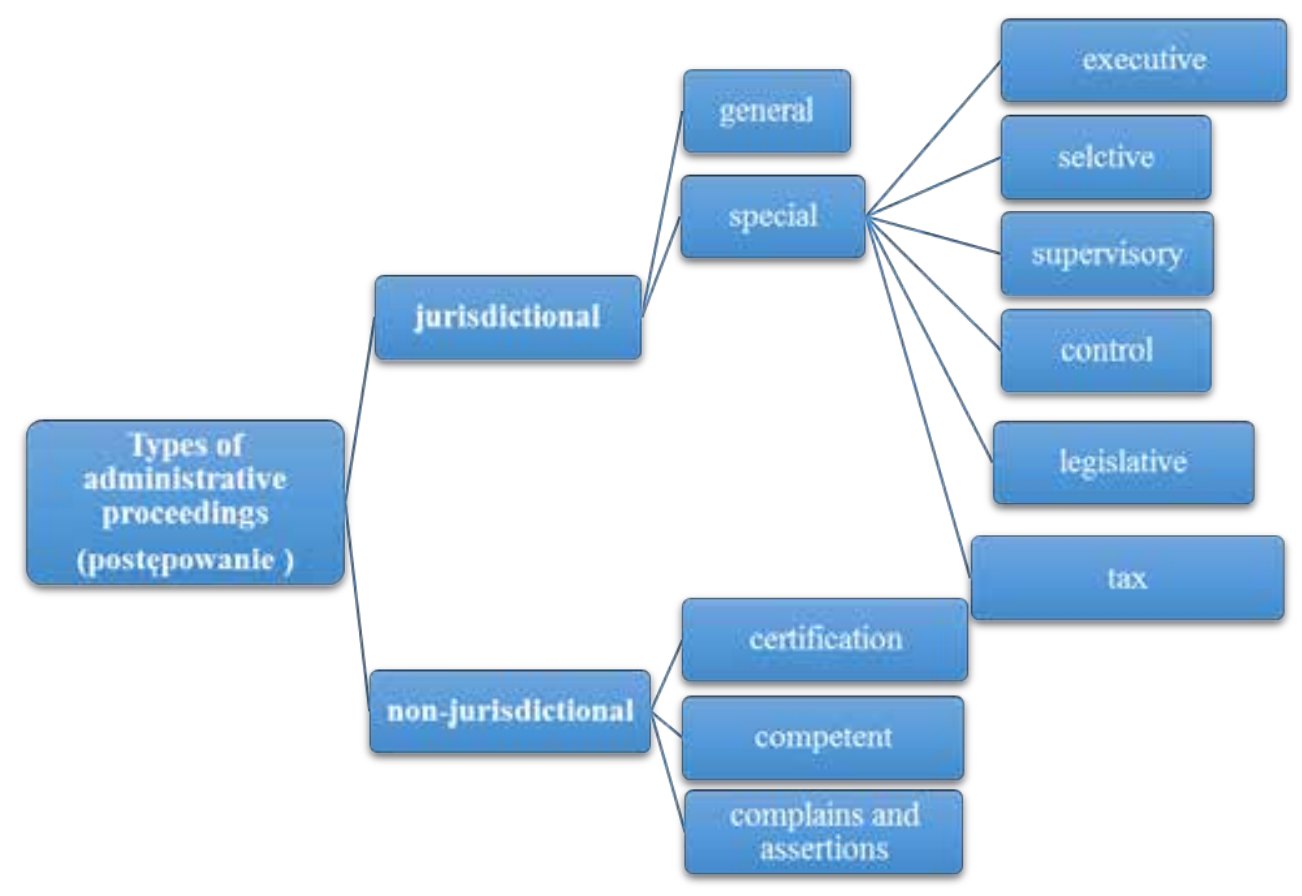

Figure 1. Types of administrative proceedings in Poland 
arising in the field of state power by its various bodies, as well as the determination of jurisdiction or other disputes arising in related fields of law. Today, the State Council is divided into five sections to carry out its activities: four sections for the control of the sphere of administration and one judicial. Management sections carry out advisory functions, and each of them is competent for a certain number of related ministries. These are sections of public works, internal affairs, finance and the social section. They oversee the most important types of management activities. The judicialjurisdictional section that supervises the consideration of disputes and conflicts is particularly distinguished. The nature of the activities of the Council of State itself should be considered in its two aspects: as a consultant to the executive branch (that is, an advisory function) and judicial and jurisdictional activity (dispute resolution function).

In France, the institute of administrative justice has been formed and functions within the executive branch, and the independence of administrative courts is achieved by their separation from bodies directly involved in public administration.

Moreover, the value of administrative courts in relation to the protection of rights and the legitimate interests of citizens and organizations in France are hard to overestimate.

The controversial administrative procedure is used to resolve issues falling within the competence of the administrative judiciary, noncontroversial refers to the activities of administrative bodies the result of which is the adoption of an administrative act (in the broad sense).

The controversial administrative procedure is governed by general legal norms and case law. A noncontentious administrative procedure is characterized by formalism regarding the activities of administrative bodies, the form of an administrative act.
This procedure was governed by legal provisions that are dispersed in various laws, decrees, decrees or orders governing individual areas of government, as well as the general principles of law, and the case-law of administrative courts, which oblige bodies to comply with their decisions with the basic requirements regarding the form of administrative acts. Today, a controversial administrative procedure is enshrined in a codified act - the Code of relations between the public and government [9].

The most important element that distinguishes a non-controversial administrative procedure from a controversial one is the provision as the right to defense.

French doctrine distinguishes three types of administrative procedure:

1) non-controversial administrative procedure;

2) non-jurisdictional disputed administrative procedure;

3) controversial procedures [8, p. 125].

According to French law, a noncontroversial administrative procedure is defined as a set of rules governing the adoption and legal status of administrative acts and decisions. Thus, the rules governing the adoption of administrative acts are part of the law on administrative procedures in France.

A non-jurisdictional controversial administrative procedure is considered in the meaning of nonjudicial administrative proceedings (proceedings), which can take two forms:

- an appeal filed with the body that adopted the act (internal appeal recoursgracieux);

- an appeal filed with a higher body (the appeal to the superior administrative authority is recourshiérarchique (hierarchical appeal)) The result of both appeals is the adoption of a new administrative act either by the same authority or by a higher authority.

The French administrative body actively uses the non-controversial 


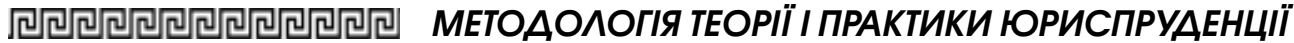

administrative procedure, since with its help the number of claims filed by citizens in administrative courts is reduced every year.

Special administrative appeals as pre-trial remedies are provided for in the texts of the law and relate to mandatory preliminary remedies on certain issues, such as: making and collecting state funds for a long time and others.

The controversial jurisdictional administrative procedure concerns disputes regarding decisions or actions of government bodies falling under the jurisdiction of administrative courts. This procedure is regulated by a special code - The Code de justice administrative. Judicial proceedings in administrative courts fall into two broad categories: litigation ultra vires (contentieux de l'excès de pouvoir) on abuse of authority when the plaintiff files a lawsuit to revoke an administrative act or on the basis of its illegality, and a full trial (pleincontentieux).

The main reasons that influenced the separation of administrative procedure into fast and undisputed are related primarily to the legal quasistatus of the State Council and to the peculiarity of the internal structure of the institution of administrative justice within the executive branch.

Having conducted a comparative legal study of the species diversity of the administrative procedure, we can draw the following conclusions in general, taking into account the considered approaches to determining individual types of administrative procedures implemented in the activities of public administration bodies, we note that most of these criteria are generally acceptable for highlighting and meaningful analysis of specific administrative procedures in the field of public administration. In the legislation of many foreign countries, the general model of administrative procedure is fixed at the level of the Law or Code.

As for the Ukrainian legislation, today, the Law "On Administrative
Procedure" is absent, therefore, all procedures automatically become special. Details of various aspects of various types of administrative procedures take place both at the level of special laws and at the level of by-laws issued by other executive bodies. The list of these acts is so extensive and heterogeneous that there can be no question of the full compliance of the provisions embodied in them with each other. Moreover, such a variety obviously causes difficulties with the search for an applicable norm for a private individual who is faced with a particular administrative procedure, and even for officials.

Analyzing the provisions of the project legislation, we note that both the Administrative Procedure Code and the Draft Law "On the Administrative Procedure" present as a general procedure the complaints and applications procedure aimed at protecting and realizing the rights and legitimate interests of citizens and the procedure initiated by the administrative body, including in the exercise of control powers. With regard to other types of administrative procedure, the draft law stipulates a special regulation (for example, in the provision of administrative services, state supervision (control) in the field of economic activity, which are carried out on the basis of the Laws of Ukraine "On Administrative Services", "On the basic principles of state supervision (control) in the field of economic activity"). We can talk about the borrowing of the Polish approach by the authors of the draft legislation, we are talking about the draft Administrative Procedure Code and the Bill on Administrative Procedure.

2) the approach of the American legislator regarding the consolidation of the types of administrative procedure is structured, since the types are presented in one act, which simplifies both research and analysis - on a theoretical level, 
so practical - in terms of application. As for Poland and France, in these countries the legislative and the doctrinal approach is a little different. Polish scientists, using the classification method, chose one criterion for distinguishing production, which, from our point of view, avoids overextensiveness, in turn, the Polish Code of Administrative Procedure reflects the general approach of the legislator regarding the consolidation of types of administrative procedures. In France, a controversial and non-controversial administrative procedure is regulated at the level of two separate codified acts the Code of Administrative Procedure and French Code on Relations between the Public and the Administration, which is an indicator of the use by the legislator of a unified approach.

The conducted comparative analysis of the species diversity of the administrative procedure will help us: firstly, to formulate a comprehensive vision and develop a unified approach, secondly, to rethink the conceptual framework within which the administrative procedure operates, and thirdly, it will provide an opportunity to introduce proposals into the project legislation.

The author conducts a comparative legal study of the types of administrative procedure, using the experience of the United States, France and Poland in order to form a conceptual overview and a systematic approach to the typology of administrative procedure.

The author monitors the procedural legislation of the above countries in order to consolidate the types of administrative procedure.

In the course of research the author comes to conclusions, in particular: in the USA types of administrative procedure depend on type of rule-making. In accordance with the provisions of the US Federal Act "On Administrative Procedure" distinguish: formal rulemaking, informal, exclusive, hybrid and conciliatory. The approach of the Polish legislator to the types of administrative proceedings differs from the approach of the American legislator in a differentiated nature. The Code of Administrative Procedure reflects the general approach, as the types of proceedings presented in it cover the main activities of public administration bodies, and as for special - the legislator has provided for special regulation.

In the legislation of many foreign countries, the general model of administrative procedure is fixed at the level of the Law or Code.

As for the Ukrainian legislation, today, the Law "On Administrative Procedure" is absent, therefore, all procedures automatically become special. Details of various aspects of various types of administrative procedures take place both at the level of special laws and at the level of by-laws issued by other executive bodies. The list of these acts is so extensive and heterogeneous that there can be no question of the full compliance of the provisions embodied in them with each other. Moreover, such a variety obviously causes difficulties with the search for anapplicable norm for a private individual who is faced with a particular administrative procedure, and even for officials.

The conducted comparative analysis of the species diversity of the administrative procedure will help us: firstly, to formulate a comprehensive vision and develop a unified approach, secondly, to rethink the conceptual framework within which the administrative procedure operates, and thirdly, it will provide an opportunity to introduce proposals into the project legislation.

Key words: types of administrative procedure, procedural legislation. 


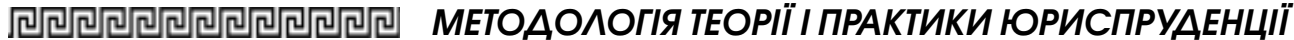

\section{Маркова О. Порівняльно- правовий аналіз видів адмі- ністративної процедури}

у статmi автор проводить порівняльне-правове дослідження видів адміністративної процедури, використовуючи досвід США, Франції та Польщі з метою формування кониептуального огляду та системного підходу в питанні типологіі адміністративної процедури. Автор проводить моніторинг процедурного законодавства вищезазначених країн на предмет закріплення видів адміністративної процедури.

У процесі дослідження автор приходить до висновків, зокрема: у США види адміністративної процедури залежать від типу нормотворчості. Відповідно до положень Федерального Акта США «Про адміністративну процедуру» виділяють: формальну нормотворчість, неформальну, виняткову, гібридну та погоджувальну.

Підхід польського законодавия щодо видів адміністративних проваджень відрізняється від підходу американського законодавия диференційованим характером. У Кодексі адміністративного провадження відображається загальний підхід, оскільки представлені в ньому види проваджень охоплюють основні напрямки діяльності органів державного управління, а що стосується специіальних, то законодавецьь передбачив спеціальне регулювання.

У законодавстві більшості зарубіжних країн загальна модель адміністративної процедури закріплена на рівні Закону або Кодексу. Що стосується українського законодавства, то сьогодні Закон «Про адміністративну процедуру» відсутній, тому всі процедури автоматично стають спеціальними. Деталізація тих чи інших аспектів різних видів адміністративних процедур відбувається як на рівні спещіальних законів, так іна рівні підзаконних актів, що видаються іншими виконавчими органами. Перелік даних актів настільки великий $і$ неодно- рідний, що мови бути не може про повну відповідність закріплених у них положень одне одному. Більи того, таке різноманіття очевидно викликае труднощі з пошуком прийнятної норми у стикається з тією чи іншою адміністративною процедурою приватної особи, $i$ навіть у посадових осіб.

Проведений компаративістський огляд видового різноманіття адміністративної процедури допоможе нам: по-перше, сформувати комплексне бачення $i$ виробити уніфікований підхід, по-друге, переосмислити концептуальні рамки, в яких функціонуе адміністративна процедура, по-трете, з'явиться можливість внести пропозиції в проектне законодавство.

Ключові слова: види адміністративної процедури, процедурне законодавство.

\section{References}

1. Administrative Procedure Act 1946. URL: / / https: / / www.archives.gov/federal-register/laws / administrative-procedure.

2. Wojciech Federczyk, Michat Klimaszewski, Bartosz Majchrzak. Podręcznik „Posteppowanie administracyjne" wyjaśnia problematyke postępowań. Wydanie: 5. Rok: 2018. s. 427.

3. Z. Cieślak, I. Lipowicz, Z. Niewiadomski, Prawo administracyjne. Część ogylna, Warszawa 2002, s. 56.

4. Ustawa z dnia 14 czerwca 1960 r. Kodeks postępowania administracyjnego (tekst jednolity: Dz.U. z 2013 r., poz. 267).

5. Adamiak B., Borkowski J., Postępowanie administracyjne $i$ sadowo administracyine, Warszawa 2004. S. 125.

6. Jaśkowska M., Wrybel A., Kodeks postępowania administracyjnego. Komentarz, LEX 2013. 567.

7. Laszczyca G., Martysz Cz., Matan A., Kodeks postępowania administracyjnego. Komentarz. Tom I. Komentarz do art. 1-103, LEX 2010. 624.

8. Jean-Bernard Auby. Codification of Administrative Procedure. Bruylant, Nov 27, 2013 - Law - 444 p.

9. French Code on Relations between the Public and the Administration 2016. URL: https: / / ec.europa.eu/digital-single-market / en / news / provisions-french-code-administration-implementing-psi-directive-january-2017-consolidated. 